\title{
The Failure of Korea Inc.
}

\section{Heather Smith}

$\mathrm{P}$ rior to 1997 Korea was one of the world's great economic success stories. Between 1962-90, the economy grew at an average annual rate of 9 per cent. Even before the 1997 crisis, Korea's macroeconomic performance looked impressive, with the economy averaging annual growth of 7.7 per cent between 1990-96. This stellar growth performance was characterised by a remarkable degree of macroeconomic stability, the pursuance of an outwardlooking development strategy based on the expansion of exports, and considerable investment in human capital.

Yet, Korea's rapid industrialisation was also characterised by extensive government intervention in the allocation of resources, especially during the 1970s. State-directed lending and administrative guidance worked well enough in the early stages of development when the economy was relatively simple and the way to increase production was to invest heavily. But it left in its wake an industrial structure characterised by a high degree of economic concentration, overly-indebted firms, and a distorted financial system with limited experience in managing risk. Over time, as the economy became more open and more complex, the cost-benefit ratio of government involvement worsened (Sakong, 1993:4). In the end, the systemic risks created by these unreformed components of policy prevented the putting into place of the structural and institutional reforms required to adapt to a changing domestic and international environment.

\section{Economic Development in the 1960s and 1970s}

After seizing power in 1961 President Park Chung Hee's goal was the rapid industrialisation of Korea through the creation of a highly centralised and ambitious economic development program. From the early 1960 s to 1972 , an export-oriented development strategy was implemented through extensive market and non-market incentives. An important step in this strategy was the 1964 devaluation of the currency, which was accompanied by the introduction of sliding-peg system of adjustment aimed at preventing real appreciation of the currency. The government established export targets at the industry level and rewarded successful exporters. Exporters were supported by various fiscal and financial subsidies, given permission to retain foreign exchange earnings for the

Heather Smith is Research Fellow in the Division of Economics, Research School of Pacific and Asian Studies/Asia Pacific School of Economics and Management at The Australian National University. 
purchase of imports, and exempted from virtually all import controls and tariffs, allowing them to obtain inputs at world prices (OECD, 1994:18). Incentives were designed to promote exports in general rather than specific industries, and to offset existing import-substitution biases. In essence, they were to get relative prices right rather than to get them 'wrong' (Sakong, 1993:38).

Despite economic growth of 8.7 per cent, and average export growth of 39 per cent between 1962-71, the government in 1972 announced plans to shift from general export promotion to the targeting of heavy and chemical industries. This plan, known the Heavy and Chemical Industry (HCI) drive (1973-79) was adopted for three reasons. First, the need to upgrade the industrial structure to maintain export growth in view of increased competition in light manufactures from other developing countries (OECD, 1994:18-19). Second, it was reasoned that the negative effects from developed countries rising protectionist barriers to labour-intensive manufacturing products could be offset by exporting higher valued-added capital-intensive products. Third, the US announcement that troops stationed in Korea would be reduced by a third in 1971, gave rise to concerns of an eventual withdrawal of US troops from the Korean peninsula. These security concerns prompted the promotion of heavy industry as the foundation of a strong defence industry (Kim, 1997).

Under the HCI plan, industry-neutral incentives for exports were replaced by industry-specific, and in some cases, firm-specific measures. Industries designated as 'strategic' included steel, shipbuilding, heavy machinery, petrochemical, industrial electronics and non-ferrous metal industries. The main tools of promotion were tax incentives and preferential access to bank credit. Over the course of the plan, almost 60 per cent of total bank loans and more than 75 per cent of total manufacturing investment went to these sectors, stifling the flow of funds available to light manufacturing industries. Investment, in turn, was funded predominantly by external borrowings, resulting in a rapid rise in foreign debt from 25 per cent of GNP in 1970 to 49 per cent by 1980 .

While the industrial conglomerates (chaebol) ${ }^{1}$ have always played a major role in Korea's economic development, their period of most rapid growth was during the $\mathrm{HCl}$ drive. The government relied heavily on the conglomerates to develop these industries because they possessed the organisational and technical abilities to compete with foreign enterprises. Good performers were rewarded with licences to expand into more lucrative sectors, thus leading them to further diversification. On any indicator, the rapid growth and diversification of the chaebol during the 1970 s radically transformed the industrial structure and market concentration in Korea. By 1977, 93 per cent of all commodities were produced under monopoly, duopoly or oligopoly conditions in which the top

1 A chaebol is a business group consisting of varied corporate enterprises engaged in diversified business areas and typically owned and managed by one or two interrelated family groups (Kim, 1997). 
three producers accounted for more than 60 per cent of market share. Between 1973-82, the share of manufacturing output of the 20 largest groups increased from 7 per cent to 29 per cent (OECD, 1994:60). By 1980, the 10 largest chaebol accounted for 48 per cent of GNP (Kim, 1997).

The socialisation of bankruptcy risk that accompanied the plan, combined with the low interest rate ceilings, made the cost of debt financing very cheap for firms in targeted sectors, encouraging firms to take on excessively high levels of debt and to increase market share rather than profitability and shareholder value (Huh and Kim, 1994:26). Between 1963-71, the debt/equity ratio of the manufacturing sector increased more than fourfold, from 92 per cent to 488 per cent by the end of the HCI drive in 1980 .

To what extent did industry policy interventions, and especially credit, spur growth in the priority sectors? A direct answer is not possible, given the difficulty of testing the counterfactual. By the mid-1980s, those industries targeted under the heavy and chemical industries drive did become the leading industrial sectors in Korea. Yet, it is difficult to conclude that the export growth in the 1980s of products of 'heavy' industries promoted by the Korean government during the 1970 s was the result of successful government intervention. ${ }^{2}$

Yoo (1990:111), for example, notes that much of the increase in exports during the 1980 s was mostly due to exports to the United States. This increase represented a response to the surge in United States imports, which in turn was primarily the result of the Reagan administration's fiscal policy. On the price side, Korea exports were boosted from the depreciation of the real effective exchange rate, due to the depreciation of the won in 1985 against the US\$ and the appreciation of the yen and deutschmark after 1985. United States restrictions on imports form Japan, diverted some of its imports from Japan and was also particularly favourable to exports of industries targeted by the Korean government during the 1970s. These external developments contributed to a rapid increase in Korean exports to the United States and the rest of the world in the 1980 s, although there is little reason to believe that the Korean government foresaw this in the early 1970s (Smith, 1994).

\section{The 1980 Crisis}

By the late 1970 s the economy was showing signs of overheating and experiencing severe structural difficulties. The massive investment in heavy and chemical industries ended at the outset of the global and domestic economic downturn, leaving many of the heavily targeted industries of the 1970 s with

2 During the period 1972-81, merchandise exports grew at an average annual rate of 37 per cent lower than the 39 per cent per annum between 1962-71 — while export growth during the 1980s averaged 14 per cent per annum. 
severe over-capacity problems. Firm profitability had declined, and industries favoured by government targeting had extremely high debt burdens. The international competitiveness of Korean exports was also weakened as a result of high nominal wage increases in the late 1970 s, overvaluation of the Korean currency and under-investment for the development of technology and training of skilled manpower. This, combined with the second oil shock, a bad agricultural harvest, and the political instability following the assassination of President Park, saw Korea in economic crisis in 1979-80.

The result was negative growth of 3.8 per cent in 1980,30 per cent inflation and an unemployment rate of 5.2 per cent. While the crisis of 1980 and the 1997 crisis share similar preconditions, a major difference was that Korea with ample foreign exchange had little problem in servicing its debts in 1980. In 1979 , short-term borrowing comprised only 27 per cent of total foreign debt compared with around 62 per cent at the end of 1996. By June 1997, Korea's short-term debt was more than three times the size of its foreign exchange reserves, a higher ratio than for any other East Asian economy.

There are two other important differences between the 1980 crisis and the current crisis. Firstly, the depressed East Asian environment, which takes 50 per cent of Korea's export, a projected slowdown in world trade, together with weaker export prices, mean a strong external-led recovery is less likely this time around. Secondly, weak domestic demand and low international commodity prices have curbed inflationary pressures. In fact, with cost-push pressures muted and demand-pull pressures largely absent, falling real wages and real incomes during 1998 have seen deflationary pressure increase.

\section{Economic Liberalisation in the 1980s}

In response to the economic crisis in 1979-80, the Korean government set out on a major policy shift. A macroeconomic stabilisation plan was accompanied by a liberalisation of structural policies. In contrast to the $1970 \mathrm{~s}$, Korea's shift to technology-intensive industries in the 1980s was largely designed around functional policies supportive of industrial upgrading. From the mid-1980s, increasing foreign government pressure to eliminate unfair trade practices also played an important part in continuing to bring about significant changes in Korean industrial policy. The government wound back its use of direct production subsidies and ceased employing export subsidies. Trade barriers were reduced by the 1984 five-year tariff reduction plan and the number of import items receiving automatic approval was increased. Rather than directing resources to industries considered 'strategic', the government's industrial initiatives instead focused on the restructuring of declining industries and measures to promote a greater role for small-scale enterprises (Smith, 1994).

Government policy towards the chaebol shifted from one of promotion in the 1960 s and 1970 s to regulation of their growth in the 1980s. The Fair Trade Act 
of 1980 , included the prohibition of cartel practices and cross-investment among affliated companies, a ceiling on credit to the larger chaebol, and restrictions on their vertical and horizontal integration. The government also directed the $\mathbf{3 0}$ largest chaebol to restructure their businesses around three or fewer core sectors (Kim, 1997:34). However, a significant gap existed between policy pronouncements and implementation, as the chaebol continued to grow.

Limited steps were taken in the early 1980 s to liberalise the financial sector. These included the privatisation of commercial banks relaxation of entry barriers to non-bank financial markets, and the gradual opening the financial sector to foreign investment. However, it was not until the early 1990s that the Kim Ycung-sam government announced a comprehensive plan for the liberalisation of the financial sector. The so-called '1993-97 Financial Sector Reform Plan' was designed to overcome the inefficiencies introduced by the non-price allocation of credit in the economy by opening the financial sector to foreign participation and gradually removing controls on long and then short-term international capital movements. By the end of 1995 , the deregulation program had resulted in a domestic financial system that had almost complete freedom to determine its lending and borrowing rates. The pace of deregulation with respect to international capital flows was much slower, proceeding in a manner clcsely linked to macroeconomic developments. Nonetheless, several changes to regulations governing capital inflows that had been implemented between 199395 generated considerable net capital inflows in 1995 and 1996 (Smith, 1998a).

A large fraction of these capital inflows were intermediated to the corporate sector through the banking sector with domestic banks increasing their foreign short-term liabilities much faster than their foreign assets. ${ }^{3}$ The bulk of loans were used by the chaebol to expand manufacturing capacity and to branch out int new sectors. Loans were mostly short-term, with borrowers confident they colld roll them over.

By the mid-1990s, the financial health of the chaebol were once again increasingly shaky with very high debt-to-equity ratios and falling profitability. While their debt/equity ratios had fallen over the course of the 1980s, by 1996 the average debt/equity ratios of the top 30 chaebol was 389 per cent, up from 285 per cent in 1990 . During the first half of 1997, corporate sector fund rasing through the financial markets continued to rise rapidly. This expansion, which occurred despite the deceleration in growth of investment, was brought about by the increased demand for operating funds in response to the slowdown of sales and profitability. Reflecting their financial distress, the average debt/equity ratio of the top 30 chaebol by the end of 1997 had jumped to 519 per cent.

3 h the first half of the 1990s, rates of growth of lending to the private sector well in excess of noninal GDP growth, averaging annual growth of 17 per cent between 1990-96 (Corsetti et al, 19)8). 


\section{The Industrial Policy Legacy}

The most visible effect of past interventionist policies has been the increasing growth and concentration of economic power in the hands of the chaebol. Yet, policy towards the chaebol has always been complicated by the fact that these companies remained highly leveraged and highly interdependent financially. Their practice of cross-payment guarantees among units of a chaebol enabled individual companies within the conglomerate to get credit guaranteed by the assets of the entire group. This facilitated easy access to loans but also left the chaebol dangerously exposed to chain bankruptcies involving subsidiaries of the same group.

Government-imposed industry restructuring continued to emphasise mergers and bailouts rather than industrial exit, which tended to delay needed adjustments and entailed inefficient resource allocation. Moreover, the firms undergoing restructuring were mostly taken over by large business groups, contributing to the concentration of economic power. Anticipating a government rescue, the chaebol continued to expand well beyond their evident financial capability and postponed adjustments to market changes.

Another intractable problem in policy making in Korea since the late 1970s has been dealing with financially distressed firms and the large amount of nonperforming loans that have accumulated in the banking system. The majority of these firms commenced operation at the height of the heavy chemical industrialisation drive in the 1970s. In particular, industries such as shipping and foreign construction which had been selected and fostered by the government as 'strategic' industries in the 1970s faced severe structural depression in the early 1980s.

Reform of the financial sector has always been complicated by the fact that the banking system did not adequately deal with the losses it had suffered during earlier periods of more pervasive government-directed lending. While the government permitted banks greater discretion in setting interest rates and allocating loans, government control of the banking sector still persisted. Asset portfolios of commercial banks were still constrained by specific limits on lending to large companies and subsidised lending from the central bank still distorted credit markets. Insider relationships between banks and borrowers still served to channel credit without regard for rates of return and at rates below the cost of funding.

If the banking sector has always been weak, why had the banks not become a problem before 1997? Much of the explanation lies with the implicit coinsurance scheme among government, banks, and industry; and the lax prudential supervision standards which allowed a sharp deterioration in the quality of the loan portfolios of financial institutions following financial liberalisation in the first half of the 1990s (Smith, 1998a). Banks failed to 
strengthen their credit evaluation criteria and chose the traditional stance of supporting the expansion of the chaebol. Implicit guarantees that banks not be allowed to fail created an incentive for banks to take lending risks, while the introduction of deposit insurance scheme in 1992 effectively removed the need for depositors to monitor the health of banks.

While commercial banks had accumulated provisions that exceeded the value of their bad loans at the end of 1995, and capital adequacy ratio of commercial banks were above Bank for International Settlements (BIS) requirements, standards of disclosure of non-performing loans were much weaker and the Korean definition of bad loans much narrower than in many OECD countries (OECD, 1996). ${ }^{4}$ By the Korean definition, 22 of its 26 banks met the BIS capital adequacy ratio of eight per cent by the end of 1997 . However on the assumption of full provisioning for loan losses and unrealised securities losses the average capital ratio was seven per cent as of the end of 1997 . In this case only 12 banks were over the minimum standard.

In practice, the government averted periodic bankruptcy of large enterprises by directing banks to provide relief loans or rescheduling debt (Huh and Kim, 1994:26). Special allowances in financial reporting were often made which created difficulties in comparing performance with previous years - for example, by not requiring banks to fully reserve for investment securities losses and the deferral of foreign exchange losses for Korean corporate accounts. These interventions reflected political considerations and fears of the effects of large corporate failures on the banking system - hence the government's continued involvement in keeping the financial sector solvent (Smith, 1998a).

\section{Falling Competitiveness ${ }^{s}$}

By the second half of the 1980s there were increasing signs that the Korean model of development was reaching its used-by date. Despite the export surge caused by the weak yen in the first half of the 1990s, indicators of Korea's competitiveness do not suggest a strong impetus to export growth from changes in cost factors since 1993 - the real effective exchange rate appreciated, prices of major export items fell and relative unit labour costs increased (Figure 1). Labour costs had been rising significantly since the mid-1980s, and although the rate of increase had slowed by the early 1990 s, real average monthly earnings in

\footnotetext{
4 Before the 1997 financial crisis, official statistics of non-performing loans (as measured by international standards) had never been released. At the height of the crisis in December 1997, the proportion of non-performing loans in the banking system was estimated to be $15-18$ per cent (IMF Press Release, December 4 1997).
}

5 This section draws heavily from Smith (1998a). 
manufacturing still grew by an average 7.8 per cent per year between 1992 and 1996, while productivity growth lagged.

Figure 1: Competitiveness Indicators (1991=100)

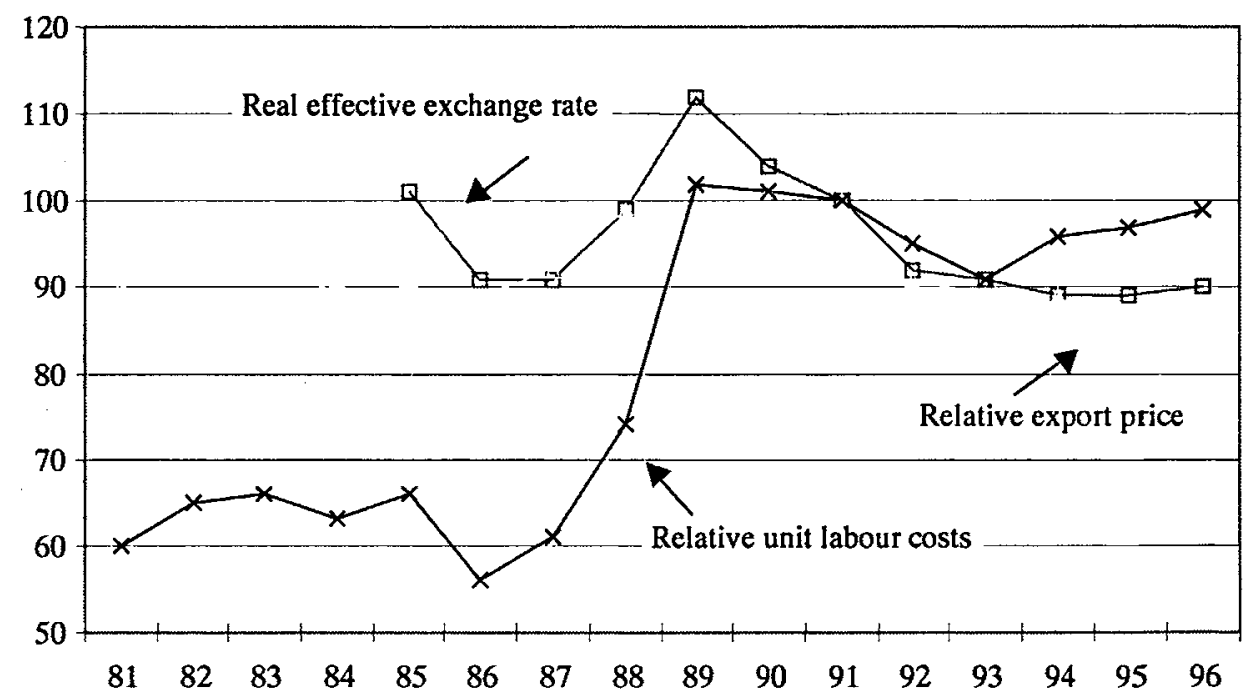

Note: Data are from OECD (1998), Annex tables 38, 43 and 44.

Source: Smith (1998a:69).

Korea's failure to maintain competitiveness in technologically advanced lines relative to its major rivals also suggests that Korea's industrial structure was increasingly hindering competitiveness. Korea was finding it harder to compete with cheaper producers in low-margin manufacturing products such as consumer electrical appliances and memory chips. Compared with Taiwan, Singapore and Japan, Korea had also been slower to shift into more sophisticated segments within these industries. Countries with low costs, such as China and Southeast Asia were also squeezing Korean firms. Korean firms had been slower to relocate investment to low-cost areas of East Asia, thereby increasingly pricing themselves out of production of goods that had emigrated to cheaper locations earlier.

While early industrial strategies and structures had enabled the chaebol to mobilise large resources and to cross subsidise risky operations, this approach increasingly became a liability, preventing firms from competing at the innovation frontier. The scale-intensive approach of the chaebol contrasted sharply with its major competitors. While Korea's major manufacturing groups tended to follow a process-driven path, Taiwan firms innovated across niche markets, on a much smaller scale (Hobday, 1995). A flexible, diversified 
production base meant firms were able to respond more quickly to rapidly changing markets and unexpected shocks such as the slowdown in export prices in 1996. Korea's competitors were also more effective in neutralising the effects of the yen's movements.

\section{The 1997 Crisis}

Under these circumstances, Korea was always vulnerable to an internal or external shock that would alter the fine balance. In the first half of the 1990s exporters were able to maintain high rates of volume growth largely because of a high degree of competitiveness with Japan in third markets, as a consequence of the depreciation of the won against the yen during the first half of the 1990s (Figure 2). But by August 1995 as the yen began to fall against the dollar, Korea lost its price advantage over Japanese competitors.

Figure 2: Real Effective Exchange Rate 1985 to January 1998 (1990=100)

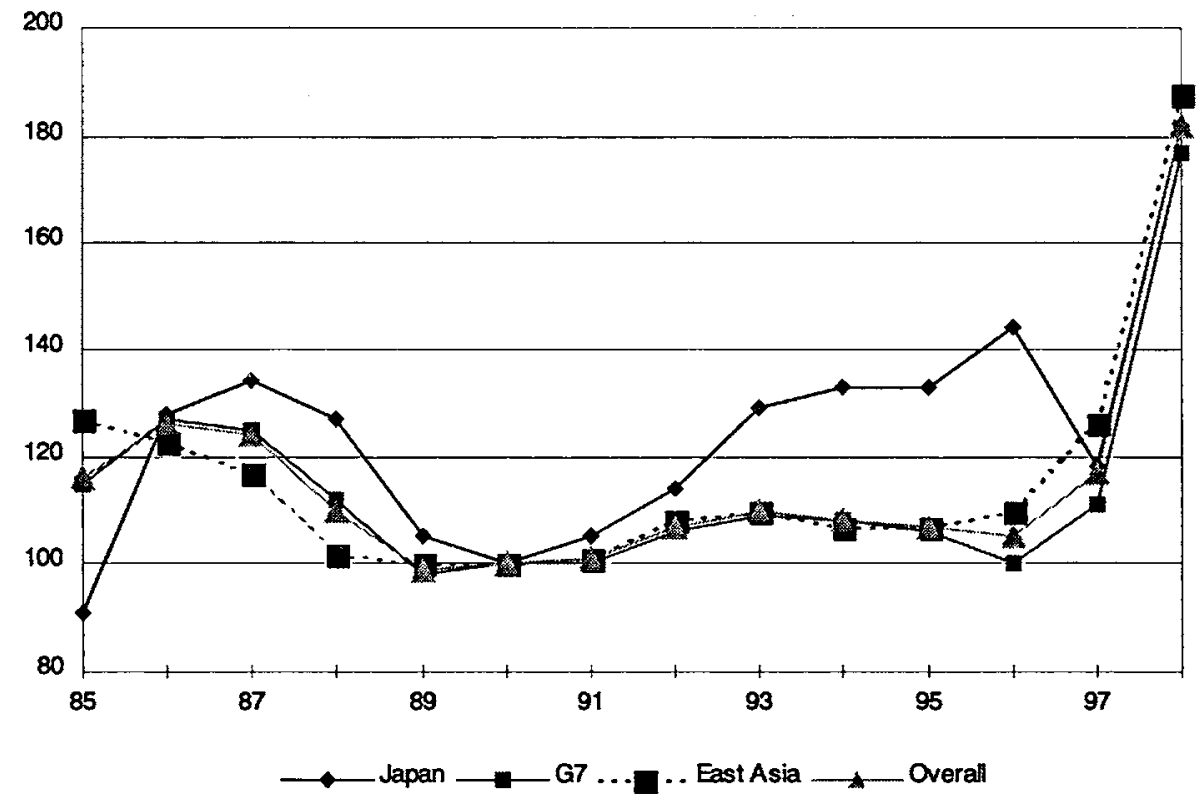

Notes: The real exchange rate is calculated by adjusting the nominal exchange rate for differences in the rate of inflation between the home country and its trading partners. The inflation rate is measured by the CPI. A rise in the value of the index indicates that prices in the home country have fallen relative to those on average in its trading partners. As a result, the international competitiveness of the home country will have improved.

Source: Smith (1998b:76). 
In 1996, Korea suffered another deterioration in its terms of trade caused by the sharp fall-off in the prices of main export products, notably semiconductors. As a result, export prices in 1996 fell by 15 per cent. Merchandise export growth slowed sharply to 5 per cent in 1996 from 32 per cent in 1995 . As the export boom slowed in 1995, corporate profits in 1996 (as measured by the ratio of ordinary income to sales), fell below one per cent, their lowest level ever. Unable to generate sufficient cash flow to service their short-term debts, eight of the top 30 chaebol were effectively insolvent by mid-1997. Corporate bankruptcies in turn led to serious difficulties for the banks, especially merchant banks that had borrowed heavily abroad to finance investment projects of the chaebol (Corsetti et al, 1998:57). All of this had occurred well before the onset of the currency crisis in Thailand in July 1997.

The bankruptcies resulted in a severe deterioration in the balance sheets of Korean financial institutions. The onset of the crisis in Thailand brought Korea's financial and corporate sector problems into sharp focus and increased the concerns of foreign creditors about the soundness of the financial system. In the weeks that followed, credit lines to Korean banks were cut severely and useable foreign exchange reserves fell to critically low levels as the Bank of Korea provided emergency foreign exchange support to banks to avoid default (International Monetary Fund (IMF), 1997).

While the seeds for the crisis were sown in the early $1970 \mathrm{~s}$, much of the blame for the current crisis is likely to rest with the administration of Kim Young-sam (1992-97). In making segyehwa (globalisation) his slogan, Kim's most important achievement was in preparing Korea for entry into the OECD in late 1996 and in implementing the 'real name financial transaction system', under which money could no longer be placed in bank accounts under pseudonyms.

However, the legacy of the Kim Young-sam administration lay in the failure to break the government-business-financial institution nexus and to reform the institutional framework that guided business activities in Korea. In attempting to slim down the chaebol, Kim began his term by initiating investigations into the complex system of cross-shareholdings among the chaebol's parent companies and their network of subsidiaries, and by seeking to limit the amount of credit available to these groups. However, the government then sent ambiguous and at time contradictory signals on how it wished to deal with the chaebol, with the process slowing after 1994 because of concerns that restrictions on their activities could impact adversely on growth given their large share in domestic production and trade (Smith, 1998b). Rather than scaling them back, the chaebol actually grew larger. Between 1994 and the end of 1997, the aggregate number of subsidiaries of the 30 largest chaebol increased from 616 to 819 .

Despite measures gradually to liberalise Korea's financial markets, the process was not well sequenced nor accompanied by the necessary reform and strong prudential supervision of the financial system. Controls on short-term 
external borrowing by banks were eased, but controls on medium and long-term capital remained in place. Debt remained the primary source of external finance, in part reflecting the low default risk perceived by firms, and past administrative controls that led to a lack of innovation in other capital markets. The build-up of short-term liabilities during the 1990s largely reflected the limited availability of domestic sources of funds. As a result, the chaebol and their subsidiaries continued to monopolise bank credit, forcing smaller firms to access risky and costly credit markets.

The regulated financial sector still perpetuated the concentration of power in the hands of the chaebol, which in turn increased their political influence and created a culture of illicit financial transfers from companies to politicians. This was reflected in the so-called 1996 'slush fund' scandal where two former Presidents were jailed for amassing money in the form of bribes from business leaders in exchange for lucrative contracts, preferential loans and tax favours. In 1997, President Kim Young-sam's son and several presidential aides were convicted of using political influence in exchange for bribes, to arrange for bank loans for Hanbo Steel, Korea's second largest steel maker. ${ }^{6}$

\section{A Turning Point?}

While the IMF prescriptions for restructuring of the financial and corporate sector are consistent with the causes of the crisis, during the first few months of the crisis there was considerable debate among the government, bureaucracy and private sector as to the optimal sequencing of corporate and financial restructuring. In practice, the new government of Kim Dae-jung has supported the view of the IMF, and pursued the two restructuring tasks simultaneously, although the pace of restructuring has been slower in the corporate sector.

For the financial sector, the government's strategy has been to force nonviable banks to exit. Those banks that by June 1998 had failed to meet capital adequacy guidelines and showed little prospects of being able to be rehabilitated have been closed. The remaining banks are being restructured through the injection of public funds for the purchase of non-performing loans and through recapitalisation via mergers and the injection of foreign capital.

To date, progress in corporate restructuring has been government-led rather than chaebol-led. Under the reform program, the chaebol are required to lower their debt-equity ratios to 200 per cent by the end of 1999 and to eliminate

\footnotetext{
6 Hanbo Steel collapsed in January 1997 with debts of $\$$ US6.7 billion after failing to meet $\$ 1.7 \mathrm{~m}$ in maturing bills. The sheer magnitude of Hanbo's leverage attracted political attention and questions as to how Hanbo had borrowed 16 times its own capital to build a steel complex. A parliamentary committee hearing revealed that the government had instructed Korea First Bank to provide almost unlimited capital to the steel maker.
} 
existing cross-debt guarantees amongst subsidiaries by March 2000 . To meet these targets, the chaebol will have to streamline their operations and focus on their core business lines. Several other reforms to restructure the industrial sector are designed to enhance transparency, improve corporate governance, improve bankruptcy procedures, and strengthen competition law. Increased foreign participation and a greater role for minority shareholders is also being encouraged to pressure the chaebol to restructure.

The government has sought to enforce structural reform of the top five chaebol by requiring them to reduce their subsidiaries through sales, mergers, and the swapping of business lines among each other. This has clearly created a dilemma. The chaebol are unlikely willingly to scale down their activities. Bank-led restructuring of the chaebol is also problematic. Commercial banks have little experience in handling corporate failures and have weak bargaining power over the chaebol. Yet, despite concerns as to the current role of the government in the restructuring process, there is also a general realisation that the government will have to play a major role in rectifying the problems given the reluctance of the chaebol to reform, and the fact the government at present is the only player with the resources with which to resolve the crisis.

Ultimately, Kim Dae-jung's vision is to reshape the industrial structure in such a way as to maintain Korean competitiveness. In the absence of change, there is the real risk that Korea's industrial structure will remain narrowly based, caught between high technology economies such as Japan and low cost producers such as China. Current reforms are clearly designed to provide for a more balanced industrial structure through a greater role for innovative SMEs, greater foreign participation, and the privatisation of state-owned enterprises.

These reforms will see the top 30 chaebol undergo considerable rationalisation over the next five years. It is not yet clear though what the government's longer-term objective is for the top five chaebol - to streamline or to dismantle some of them. Forcing the top five chaebol to swap their subsidiaries could see an increased concentration and monopolisation of key sectors such as autos, semiconductors and electronics, which is in clear breach of the government's existing competition policy guidelines (Smith, 1999).

\section{Lessons from Korea}

Much has been made of the political relationship between the government and the private sector, and how this contributed to coherent and credible policy making. Industry policy interventions were considered to be dynamically efficient because of the institutional capacity of the state to 'discipline' business use of them (Amsden, 1989). This institutional structure had both advantages and drawbacks. On the one hand, the centralisation of power permitted flexibility in the formulation and implementation of policy, especially in the early stages of development. With little interference from interest groups, the 
leadership could respond swiftly to events. Compared with other developing countries Korea is most striking for the vigour with which macroeconomic policy adjustments were undertaken, especially following the two oil shocks (Haggard, Cooper and Collins, 1994:6). However, over time the absence of a system of checks and balances in the political and economic decision-making process became an obstacle to structural adjustment. The government-businessbanking triad thrived, and corruption and moral hazard became endemic. In particular, rent seeking associated with credit allocation remained substantial, and its distribution continued to constitute the major government tool for corporate governance and industrial policy (Cho, 1996).

The Korean experience suggests that the cost of an industrialisation strategy based on pervasive industry policy interventions can be substantial and that these costs are exacerbated as economic development advances. Many of the earlier interventions became not only redundant but also harmful to the efficient allocation of resources, resulting in serious structural imbalances in the economy. Worse still, the distortions created by the unreformed components of policy have made Korea's transition to the next phase of economic development more difficult and painful that it would otherwise have been.

\section{References}

Amsden, A. (1989), Asia's Next Giant, Oxford University Press, New York.

Cho, Soon (1994), The Dynamics of Korean Economic Development, Institute for International Economics, Washington DC.

Cho, Yoon Je (1996), 'Government Intervention, Rent Distribution, and Economic Development in Korea', in Masahiko Aoki, Hyung-ki Kim and Masahiro Okuno-Fujiwara (eds) The Role of Government in East Asian Economics Development, Clarendon Press, Oxford.

Corsetti, G., P. Pesenti and N. Roubini (1998), 'What Caused the Asian Currency and Financial Crisis', mimeo. http://www.stern.nyu.edu/"nroubini/asia/AsiaHompage.html

Haggard, S., R. Cooper \& S. Collins (1994), 'Understanding Korea's Macroeconomic Policy' in S. Haggard, R. Cooper, S. Collins, Choongsoo Kim and Sung-Tae Ro (eds) Macroeconomic Policy and Adjustment in Korea, 1970-1990, Harvard University Press, Cambridge.

Hobday, M. (1995), Innovation in East Asia, Edward Elgar, UK.

Huh, Chan. and Sun Bae Kim (1994), 'Financial Regulation and Banking Sector Performance: A Comparison of Bad Loan Problems in Japan and Korea', Economic Review, Federal Reserve Bank of San Francisco (2):18-29.

IMF (1997), World Economic Outlook: Interim Assessment, December.

Kim, Linsu (1997), Imitation to Innovation, Harvard Business School Press, Massachusetts. 
OECD (1994), OECD Economic Survey — Korea, Paris.

OECD (1996), OECD Economic Survey — Korea, Paris.

OECD (1998), OECD Economic Outlook, Paris.

Sakong, Il (1993), Korea in the World Economy, Institute for International Economics, Washington DC.

Song, Byung-Nak (1990), The Rise of the Korean Economy, Oxford University Press, Oxford.

Smith, H. (1994), 'Korea's Industry Policy in the 1980s', Pacific Economic Papers, No. 229.

Smith, H. (1998a), 'Korea' pp. 66-84 in R. McLeod and R. Garnaut (eds), East Asia in Crisis: From Being a Miracle to Needing One?, Routledge, London.

Smith, H. (1998b), 'Korea', Asia Pacific Profiles 1997, FT Newsletters \& Management Reports, Hong Kong, 65-101.

Smith, H. (1999), Financial Reform and Macroeconomic Policy Management in Korea, APEC Economies Program Report No.29 (forthcoming), Asia Pacific School of Economics and Management, Australian National University.

Yoo, Jungho (1990), 'The Industrial Policy of the 1970s and the Evolution of the Manufacturing Sector in Korea', Korea Development Institute, Seoul (Working Paper No. 9017).

I wish to thank the referees for their helpful comments. 